\title{
TCF $7 L 2$ single nucleotide polymorphisms, cardiovascular disease and all-cause mortality: the Atherosclerosis Risk in Communities (ARIC) study
}

\author{
S. J. Bielinski • J. S. Pankow • A. R. Folsom • \\ K. E. North • E. Boerwinkle
}

Received: 9 January 2008 / Accepted: 17 March 2008 / Published online: 24 April 2008

(C) Springer-Verlag 2008

\begin{abstract}
Aims/hypothesis We hypothesised that TCF7L2 single nucleotide polymorphisms (SNPs) are associated with cardiovascular disease (CVD) and that the associations differ in diabetic and non-diabetic persons.

Methods Our analysis included black and white participants from the Atherosclerosis Risk in Communities study who were free of prevalent CVD at baseline and had been genotyped for rs7903146, rs12255372, rs7901695, rs11196205 and rs7895340 $(n=13,369)$. Cox proportional hazard regression was used to estimate the associations between polymorphisms and incident events; logistic and linear regression were used for associations with baseline risk factor levels.

Results TCF7L2 SNPs were not significantly associated with incident coronary heart disease, ischaemic stroke, CVD, prevalent peripheral artery disease (PAD) or all-cause mortality in the full cohort or when stratified by race.

Conclusions/interpretation In the whole cohort, TCF7L2 SNPs were not associated with incident CVD, all-cause mortality or prevalent PAD. This result suggests that the
\end{abstract}

S. J. Bielinski $(\bowtie) \cdot$ J. S. Pankow $\cdot$ A. R. Folsom Division of Epidemiology and Community Health, University of Minnesota,

1300 South 2nd Street, Suite 300,

Minneapolis, MN 55454, USA

e-mail: suzetteb@umn.edu

K. E. North

Department of Epidemiology, University of North Carolina,

Chapel Hill, NC, USA

E. Boerwinkle

Human Genetics Center,

University of Texas-Houston Health Science Center,

Houston, TX, USA increased health risk associated with rs7903146 genotype is specific to diabetes.

Keywords All-cause mortality. Cardiovascular disease . Coronary heart disease - Diabetes · Peripheral artery disease . Stroke $\cdot$ TCF7L2 Transcription factor 7-like 2

Abbreviations
$\begin{array}{ll}\text { ARIC } & \text { Atherosclerosis Risk in Communities } \\ \text { CVD } & \text { cardiovascular disease } \\ \text { IMT } & \text { intima-media thickness } \\ \text { PAD } & \text { peripheral artery disease } \\ \text { SNP } & \text { single nucleotide polymorphism } \\ \text { TCF-4 } & \text { transcription factor } 4\end{array}$

\section{Introduction}

Diabetes is a major risk factor for stroke, peripheral artery disease (PAD) and CHD. Polymorphisms of TCF7L2 have been associated with diabetes in numerous studies [1-3] and the magnitude of risk conferred by TCF $7 L 2$ variants is greater than for any previously described common variant. The single nucleotide polymorphism (SNP) rs7903146 is the most highly associated of the known variants and is associated with a $40 \%$ increased risk of diabetes per allele [4]. The gene TCF7L2 is located on chromosome 10 and encodes the transcription factor 4 (TCF-4). Interestingly, a specific role for TCF-4 has been shown in the process of vascular remodelling. Moreover, transcriptional activation of TCF-4 turns on the nuclear factor- $\mathrm{kB}$ signalling pathway, which regulates inflammatory signalling pathways [5]. Data from the MONICA/KORA Surveys showed that the T allele of rs7903146 was inversely associated with homeostasis 
model assessment of per cent beta cell function and fasting insulin, suggesting a role in pancreatic beta cell function [3]. Thus, depleting islet cells of TCF7L2 in culture resulted in significant increases in beta cell apoptosis and decreases in proliferation and glucose-stimulated insulin secretion [6]. We therefore hypothesised that TCF7L2 SNPs would be associated with cardiovascular disease (CVD) in the Atherosclerosis Risk in Communities (ARIC) Study. Furthermore, we investigated whether the associations between TCF7L2 genotypes and CVD differ in ARIC participants with and without diabetes.

\section{Methods}

The ARIC study is a prospective cohort study of 15,792 participants investigating the development of atherosclerosis and described in detail elsewhere [7]. Written informed consent was obtained from each study participant prior to data collection at each exam. For the present analysis, individuals were excluded on the basis of the following criteria: race other than black or white $(n=48)$; black participants from centres with small numbers $(n=55)$; prevalent CHD ( $n=763)$; missing data for prevalent CHD $(n=339)$; prevalent stroke $(n=264)$; and missing genotype data for TCF7L2 SNP rs7903146 $(n=954)$. The final analysis sample included 13,369 participants. In addition, individuals for whom ankle-brachial index values were missing were excluded $(n=457)$ from the investigation of associations between TCF7L2 and PAD. Ascertainment and standardised case definitions for PAD [8], CHD [9], stroke [10], carotid intima-media thickness (IMT) [11], mortality [12] and diabetes [13] have been described elsewhere as indicated. Five TCF7L2 SNPs (rs7903146, rs12255372, rs7901695, rs11196205 and rs7895340) were genotyped on stored DNA using the TaqMan system (Applied Biosystems, Foster City, CA, USA). Some samples (5\%) were regenotyped for quality control and 726 ARIC participants were genotyped in duplicate. The percentage of agreement was $96 \%$ and simple kappa coefficient was 0.93 , indicating good genotype quality. All data were analysed with SAS, version 9 (SAS Institute, Cary, NC, USA). We tested for Hardy-Weinberg equilibrium using the $\chi^{2}$ goodness of fit test. Cox proportional hazard regression was used to estimate the associations between SNPs and incident events; logistic and linear regression were used for baseline prevalence measures. We had $80 \%$ power to detect a relative risk of 1.17 for incident CHD with an alpha level at $p=0.05$.

\section{Results}

The study population included $27 \%$ black individuals and $57 \%$ women, with a mean population age of 54 years. All five SNP genotype frequencies were in Hardy-Weinberg equilibrium. The following results focus on rs7903146. Baseline diabetes, current smoking, life-time smoking exposure (pack-years) and BMI $\left(\mathrm{kg} / \mathrm{m}^{2}\right)$ differed by genotype. For the CC, CT and TT genotypes, respectively, the baseline prevalence of diabetes was 9.4, 12.2 and $14.2 \%$

Table 1 Numbers of events and HRs of incident CVD and all-cause mortality per T allele of rs7903146, ARIC 1987-2004

\begin{tabular}{|c|c|c|c|c|c|c|c|c|c|c|c|c|}
\hline & \multicolumn{4}{|c|}{ Black individuals } & \multicolumn{4}{|c|}{ White individuals } & \multicolumn{4}{|l|}{ All } \\
\hline & \multicolumn{2}{|c|}{ Minimally adjusted $^{\mathrm{a}}$} & \multicolumn{2}{|c|}{$\begin{array}{l}\text { Fully } \\
\text { adjusted }^{\text {b }}\end{array}$} & \multicolumn{2}{|c|}{ Minimally adjusted $^{\mathrm{a}}$} & \multicolumn{2}{|c|}{$\begin{array}{l}\text { Fully } \\
\text { adjusted }^{\text {b }}\end{array}$} & \multicolumn{2}{|c|}{$\begin{array}{l}\text { Minimally } \\
\text { adjusted }^{\mathrm{a}}\end{array}$} & \multicolumn{2}{|c|}{$\begin{array}{l}\text { Fully } \\
\text { adjusted }^{\text {b }}\end{array}$} \\
\hline & $n$ & $\begin{array}{l}\text { HR } \\
(95 \% \mathrm{CI})\end{array}$ & $n$ & $\begin{array}{l}\text { HR } \\
(95 \% \mathrm{CI})\end{array}$ & $n$ & $\begin{array}{l}\text { HR } \\
(95 \% \mathrm{CI})\end{array}$ & $n$ & $\begin{array}{l}\text { HR } \\
(95 \% \mathrm{CI})\end{array}$ & $n$ & $\begin{array}{l}\text { HR } \\
(95 \% \mathrm{CI})\end{array}$ & $n$ & HR $(95 \%$ CI $)$ \\
\hline CHD & 389 & $\begin{array}{l}1.12 \\
(0.96-1.3)\end{array}$ & 374 & $\begin{array}{l}1.09 \\
(0.93-1.28)\end{array}$ & 1,338 & $\begin{array}{l}1.01 \\
(0.93-1.10)\end{array}$ & 1,326 & $\begin{array}{l}1.01 \\
(0.93-1.09)\end{array}$ & 1,727 & $\begin{array}{l}1.04 \\
(0.96-1.11)\end{array}$ & 1,700 & $\begin{array}{l}1.02 \\
(0.95-1.1)\end{array}$ \\
\hline $\begin{array}{l}\text { CHD, } \\
\text { diabetes }\end{array}$ & 122 & $\begin{array}{l}1.11 \\
(0.85-1.45)\end{array}$ & 119 & $\begin{array}{l}1.04 \\
(0.79-1.36)\end{array}$ & 263 & $\begin{array}{l}1.19 \\
(0.99-1.4)\end{array}$ & 260 & $\begin{array}{l}1.21 \\
(1.01-1.44)\end{array}$ & 385 & $\begin{array}{l}1.16 \\
(1.0-1.35)\end{array}$ & 379 & $\begin{array}{l}1.14 \\
(0.98-1.33)\end{array}$ \\
\hline $\begin{array}{r}\text { CHD, no } \\
\text { diabetes }\end{array}$ & 202 & $\begin{array}{l}1.06 \\
(0.86-1.32)\end{array}$ & 195 & $\begin{array}{l}1.07 \\
(0.86-1.33)\end{array}$ & 925 & $\begin{array}{l}0.93 \\
(0.84-1.03)\end{array}$ & 917 & $\begin{array}{l}0.92 \\
(0.83-1.02)\end{array}$ & 1,127 & $\begin{array}{l}0.95 \\
(0.87-1.04)\end{array}$ & 1,112 & $\begin{array}{l}0.94 \\
(0.86-1.04)\end{array}$ \\
\hline $\begin{array}{l}\text { Ischaemic } \\
\text { stroke }\end{array}$ & 235 & $\begin{array}{l}1.12 \\
(0.92-1.36)\end{array}$ & 221 & $\begin{array}{l}1.14 \\
(0.93-1.40)\end{array}$ & 314 & $\begin{array}{l}0.99 \\
(0.83-1.17)\end{array}$ & 311 & $\begin{array}{l}0.97 \\
(0.82-1.16)\end{array}$ & 549 & $\begin{array}{l}1.04 \\
(0.91-1.18)\end{array}$ & 532 & $\begin{array}{l}1.04 \\
(0.91-1.18)\end{array}$ \\
\hline CVD & 594 & $\begin{array}{l}1.10 \\
(0.98-1.25)\end{array}$ & 567 & $\begin{array}{l}1.10 \\
(0.98-1.25)\end{array}$ & 1,594 & $\begin{array}{l}1.0 \\
(0.93-1.08)\end{array}$ & 1,578 & $\begin{array}{l}0.99 \\
(0.92-1.07)\end{array}$ & 2,188 & $\begin{array}{l}1.03 \\
(0.96-1.10)\end{array}$ & 2,145 & $\begin{array}{l}1.02 \\
(0.95-1.08)\end{array}$ \\
\hline $\begin{array}{l}\text { All-cause } \\
\text { mortality }\end{array}$ & 757 & $\begin{array}{l}1.01 \\
(0.91-1.13)\end{array}$ & 726 & $\begin{array}{l}0.99 \\
(0.89-1.11)\end{array}$ & 1,354 & $\begin{array}{l}1.03 \\
(0.95-1.12)\end{array}$ & 1,331 & $\begin{array}{l}1.00 \\
(0.92-1.08)\end{array}$ & 2,111 & $\begin{array}{l}1.03 \\
(0.96-1.09)\end{array}$ & 2,057 & $\begin{array}{l}1.00 \\
(0.93-1.07)\end{array}$ \\
\hline
\end{tabular}

${ }^{\mathrm{a}}$ Adjusted for age and sex; race in the combined analysis

${ }^{\mathrm{b}}$ Minimally adjusted variables +BMI, smoking status, pack-years 
$(p<0.0001)$ and the percentage of current smokers was 25 , 26 and $28 \%(p=0.03)$. The $\mathrm{T}$ allele was associated with lower mean BMI $\left(\mathrm{CC}=27.8, \mathrm{CT}=27.5, \mathrm{TT}=27.4 \mathrm{~kg} / \mathrm{m}^{2}, p=\right.$ $0.03)$ and more pack-years of smoking $(\mathrm{CC}=14.7, \mathrm{CT}=15.2$ and $\mathrm{TT}=16.3, p=0.05)$. There was no difference by genotype for age, race, sex, current drinking, ethanol intake, waist-to-hip ratio, total cholesterol, HDL- and LDL-cholesterol, triacylglycerol or systolic and diastolic blood pressure.

The $T$ allele of rs 7903146 was not significantly associated with incident CHD, ischaemic stroke or CVD, or all-cause mortality in the full cohort or when stratified by race (Table 1). In whites with prevalent diabetes, the $\mathrm{T}$ allele was associated with incident CHD, but only in the model adjusted for age, sex, BMI and smoking status (HR 1.21, $p=0.04$ ). We found no significant association of this allele with prevalent PAD or IMT (data not shown).

\section{Discussion}

We hypothesised that TCF7L2 SNPs would be associated with increased risk of CVD and all-cause mortality given the association of these variants with diabetes. In the whole cohort, rs7903146 was not associated with incident CVD, allcause mortality or prevalent PAD. The T allele of rs7903146 was associated with smoking and inversely associated with BMI in the whole cohort, and in a subset of whites with prevalent diabetes, the same allele was associated with incident CHD. Investigators of the Go-Darts Study of over 6,500 European participants reported that the $\mathrm{T}$ allele was associated with increased $\mathrm{HbA}_{1 \mathrm{c}}$ in both patient and control participants. They also reported that the $\mathrm{T}$ allele was overrepresented in individuals requiring insulin treatment and under-represented in patients managed by diet alone, suggesting that variants of $T C F 7 L 2$ may be associated with disease severity and therapeutic efficacy [14]. Therefore, a reasonable hypothesis is that the small increase in risk of CHD seen in our study may be the result of suboptimal or ineffective treatment of diabetes in the earlier onset cases. However, the increased risk observed in the white subgroup was not seen in the corresponding black subgroup (HR 1.04, 95\% CI 0.79 1.36). While the association may be spurious, given that this was one of several subgroup analyses, the inconsistency between races may result from the smaller sample size in this racial group. Among those with prevalent diabetes, we had $80 \%$ power to detect a relative risk of 1.54 and 1.78 for incident CHD in white and black participants, respectively. Clearly, replication in a larger and possibly younger diabetic population is needed to confirm or refute this finding.

In their entirety, these results suggest that while there may be a slightly increased risk of CHD in patients with earlyonset diabetes, the increased health risk associated with rs7903146 genotype is specific to diabetes.
Acknowledgements The Atherosclerosis Risk in Communities Study is a collaborative study supported by National Heart, Lung, and Blood Institute contracts N01-HC-55015, N01-HC-55016, N01HC-55018, N01-HC-55019, N01-HC-55020, N01-HC-55021 and N01-HC-55022. The authors thank the staff and participants of the ARIC study for their important contributions.

Duality of interest The authors declare that there is no duality of interest associated with this manuscript.

\section{References}

1. Grant SF, Thorleifsson G, Reynisdottir I et al (2006) Variant of transcription factor 7-like 2 (TCF7L2) gene confers risk of type 2 diabetes. Nat Genet 38:320-323

2. Humphries SE, Gable D, Cooper JA et al (2006) Common variants in the TCF7L2 gene and predisposition to type 2 diabetes in UK European Whites, Indian Asians and Afro-Caribbean men and women. J Mol Med 84:1-10

3. Marzi C, Huth C, Kolz M et al (2007) Variants of the transcription factor 7-like 2 gene (TCF7L2) are strongly associated with type 2 diabetes but not with the metabolic syndrome in the MONICA/ KORA surveys. Horm Metab Res 39:46-52

4. Helgason A, Palsson S, Thorleifsson G et al (2007) Refining the impact of TCF7L2 gene variants on type 2 diabetes and adaptive evolution. Nat Genet 39:218-225

5. Wang X, Xiao Y, Mou Y, Zhao Y, Blankesteijn WM, Hall JL (2002) A role for the beta-catenin/T cell factor signaling cascade in vascular remodeling. Circ Res 90:340-347

6. Shu L, Sauter NS, Schulthess FT, Matveyenko AV, Oberholzer J, Maedler K (2008) Transcription factor 7-like 2 regulates beta-cell survival and function in human pancreatic islets. Diabetes 57:645-653

7. The ARIC investigators (1989) The Atherosclerosis Risk in Communities (ARIC) Study: design and objectives. Am J Epidemiol 129:687-702

8. Salomaa V, Matei C, Aleksic N et al (2001) Cross-sectional association of soluble thrombomodulin with mild peripheral artery disease; the ARIC study. Atherosclerosis Risk in Communities. Atherosclerosis 157:309-314

9. Toole JF, Chambless LE, Heiss G, Tyroler HA, Paton CC (1993) Prevalence of stroke and transient ischemic attacks in the Atherosclerosis Risk in Communities (ARIC) study. Ann Epidemiol 3:500-503

10. Evenson KR, Rosamond WD, Cai J et al (1999) Physical activity and ischemic stroke risk. The atherosclerosis risk in communities study. Stroke 30:1333-1339

11. Howard G, Sharrett AR, Heiss G et al (1993) Carotid artery intimal-medial thickness distribution in general populations as evaluated by B-mode ultrasound. ARIC Investigators. Stroke 24:1297-1304

12. Lee CD, Folsom AR, Nieto FJ, Chambless LE, Shahar E, Wolfe DA (2001) White blood cell count and incidence of coronary heart disease and ischemic stroke and mortality from cardiovascular disease in African-American and White men and women: atherosclerosis risk in communities study. Am $\mathrm{J}$ Epidemiol 154:758-764

13. Brancati FL, Kao WH, Folsom AR, Watson RL, Szklo M (2000) Incident type 2 diabetes mellitus in African American and white adults: the Atherosclerosis Risk in Communities Study. JAMA 283:2253-2259

14. Kimber CH, Doney AS, Pearson ER et al (2007) TCF7L2 in the GoDARTS study: evidence for a gene dose effect on both diabetes susceptibility and control of glucose levels. Diabetologia 50:11861191 